\title{
RESTORING LAND AND MANAGING KARST TO PROTECT WATER QUALITY AND QUANTITY AT BARTON SPRINGS, AUSTIN, TEXAS
}

\author{
Kevin Thuesen, Ph.D. \\ Wildlands Conservation Division / Water Quality Protection Lands Program, 3621 South FM 620, Austin, Texas, \\ 78738,USA, kevin.thuesen@austintexas.gov
}

\begin{abstract}
The Water Quality Protection Lands program was established in 1998 based on a bond proposal passed to protect Barton Springs in the heart of Austin, Texas. Barton Springs is a popular swimming area for citizens and is also home to at least one federally endangered species of salamander. The initial bond called for 6,070 hectares of land to be protected. Land acquisition has benefitted from additional bonds since then as well the use of grants to raise the total acreage to over 10,731 hectares at present. Additional cost saving measures such as the use of conservation easements have allowed these dollars to be stretched further. Science has helped guide the acquisition of land into more productive geographic areas (based on recharge) and helped direct the management of these lands to further benefit water quality and quantity. Land management focuses on ecological restoration of vegetation back to native prairie and savanna ecosystems which provide optimal water yield from the land based upon the inverse relationship between woody cover and water yield. These restoration actions combined with proper karst management protects both water quality and water quantity recharging through these lands.
\end{abstract}

\section{Introduction}

The Barton Springs segment of the Edwards Aquifer is a segment of the much larger Edwards Aquifer approximately 250 kilometers in areal extent (Hunt et al 2005) and is located in Travis and Hays Counties, Texas. The aquifer primarily discharges at Barton Springs, which is a collection of four main springs located near downtown Austin, Texas (BSEACD 2003). The springs are home to the federally endangered Barton Springs salamander (Eurycea sosorum) and the rare Austin blind salamander (Eurycea waterlooensis), which is a candidate for Federal listing as endangered (BSEACD 2003). At the same time, Barton Springs provides base flow for the Colorado River and is a popular swimming destination for citizens as well as a rallying point for many environmental issues in Austin. During the early 1990s, at the crescendo of issues surrounding development and the protection of Barton Springs came a call to protect Barton Springs by additional regulations including the Save Our Springs (SOS) Ordinance (Dunn 2007, Smith 2012,). Several years after the SOS ordinance was passed, bonds were proposed to further protect Barton Springs as part of the City of Austin's water supply by purchasing sensitive land over the recharge and contributing zones in fee title or conservation easement.

\section{Protecting the Land}

In May of 1998 the citizens of Austin voted to support $\$ 65$ million in bonds that would acquire land "including fee title and easements in the Barton Springs contributing and recharge zones to provide for the conservation and to maintain the safety and quality of a part of the City's water supply" (City of Austin 1998). Additional bonds, grants and other funds since then have raised the entire contribution toward this goal of land acquisition to approximately $\$ 145,000,000$. The Water Quality Protection Lands program was created to manage these lands and currently protects over 10,731 hectares.

\section{Fee Simple versus Conservation Easement}

The Water Quality Protection Lands (WQPL) Program owns land in two different ways. The first is as any land would be owned by a private individual, also referred to as fee simple land ownership. In this case the land is owned outright with all rights and obligations intact. On such fee simple lands the City can conduct land management and outreach, provide public access, and perform other activities as needed. Such land also requires the use of City funds to conduct operations and maintenance related to managing and protecting the land, including installing and maintaining fences, vehicle trails, gates and other sundry activities. This land can still be condemned by higher levels of government (county, state, or federal government). 
The other mechanism for land ownership is the conservation easement agreement. Under this scenario the City purchases the development rights and other rights that govern the allowed activities on the land in perpetuity. These are always made with willing buyers as are all real estate transactions related to the WQPL Program. One of the major limiting factors on private property rights required by these conservation easements is the amount of impervious cover allowed on the land (usually between 1 to 2 percent of the net site area). In addition, such easements also have provisions restricting the use of certain pesticides, limits on stocking rates of livestock, a requirement to manage brush on the property and other restrictions.

Such conservation easements cost the City about 50 percent of the real value of the land. Further, such lands require no outlay of City funds for operations and maintenance of the land, as these are borne by the private landowner. However, each easement is visited annually by WQPL staff to confirm compliance with the easement and provide technical assistance as requested. Occasional legal assistance is also needed to administer this work.

Currently, the WQPL protects 10,731 hectares with 3,941 hectares held in fee simple and 6,790 hectares protected by conservation easements. These purchases have resulted in protecting over 22 percent of the Barton Springs recharge zone and seven percent of the Barton Springs contributing zone. Figure 1 shows the location and type of land holdings and their locations relative to the contributing or recharge zones.

\section{Karst Science Enabling Counterintuitive Purchases}

The purchase of these lands includes a variety of factors that determine the acquisition priority of each potential property. Most relevant of these for this paper, but by no means the only priority, is the karst science that has led to relatively counterintuitive acquisitions of property far from Barton Springs.

As shown in Figure 2, the Onion Creek watershed has five different watersheds separating it from where Barton Springs discharges prior to reaching the Colorado River. Yet, the WQPL Program has made significant purchases in this watershed
The previous assumption that the most proximal creek to Barton Springs must provide the most significant amount of recharge to Barton Springs has been disproven (Hauwert 2009). Dye traces have indicated a significant flow path from Onion Creek, which is located near the southern groundwater divide (BSEACD 2003, Hauwert et al 2004a, Hauwert et al 2004b, Hunt et al 2005,) that separates water feeding the Barton Springs segment of the Edwards Aquifer to the north and the San Antonio segment of the Edwards Aquifer to the south. Studies by the City of Austin's Watershed Protection Department and the Barton Springs Edwards Aquifer Conservation District have indicated the flow rate can be remarkably rapid from this southern boundary of the recharge zone, travelling up to $11.9 \mathrm{~km}$ per day to reach Barton Springs under high flow conditions (Hunt et al 2006). This suggests a major groundwater flow route. In addition, relative to other local watersheds, Onion Creek provides by far the greatest volume of water to the Barton Springs aquifer (Hunt et al 2005), with an estimated 33 percent of the total discharge of Barton Springs originating in Onion Creek (Hauwert 2012). This has led to some significant land purchases almost $31 \mathrm{~km}$ from Barton Springs and near the furthest extent of the recharge zone for Barton Springs.

\section{Land Management}

Owning or otherwise protecting land, such as by conservation easements, provides the greatest measure of protection from impacts such as potential pollutant sources and further allows the natural conditions that feed Barton Springs to continue unimpeded into the future. However, simply purchasing the land or rights cannot curtail the transition or succession of land into ecological states that may produce lower water yields than other ecological states. In the central Texas area grassland and savanna can quickly transition into dense woody canopy following invasion by brush species (Fowler and Simmons 2008). Previously such invasions have been reversed over the evolutionary history of the area by the frequent occurrence of natural wildfires, which have been prevented in the post-settlement era (Bray 1904, Smeins and Fuhlendorf 1997).

The concept of an inverse relationship between woody canopy cover and water yield has been demonstrated in the literature from around the world (Thurow 1998, Wu et al 2001, Le Maitre et al 2002, Davie and Fahey 2005, Hamilton 2008, Mark and Dickinson 2008). 


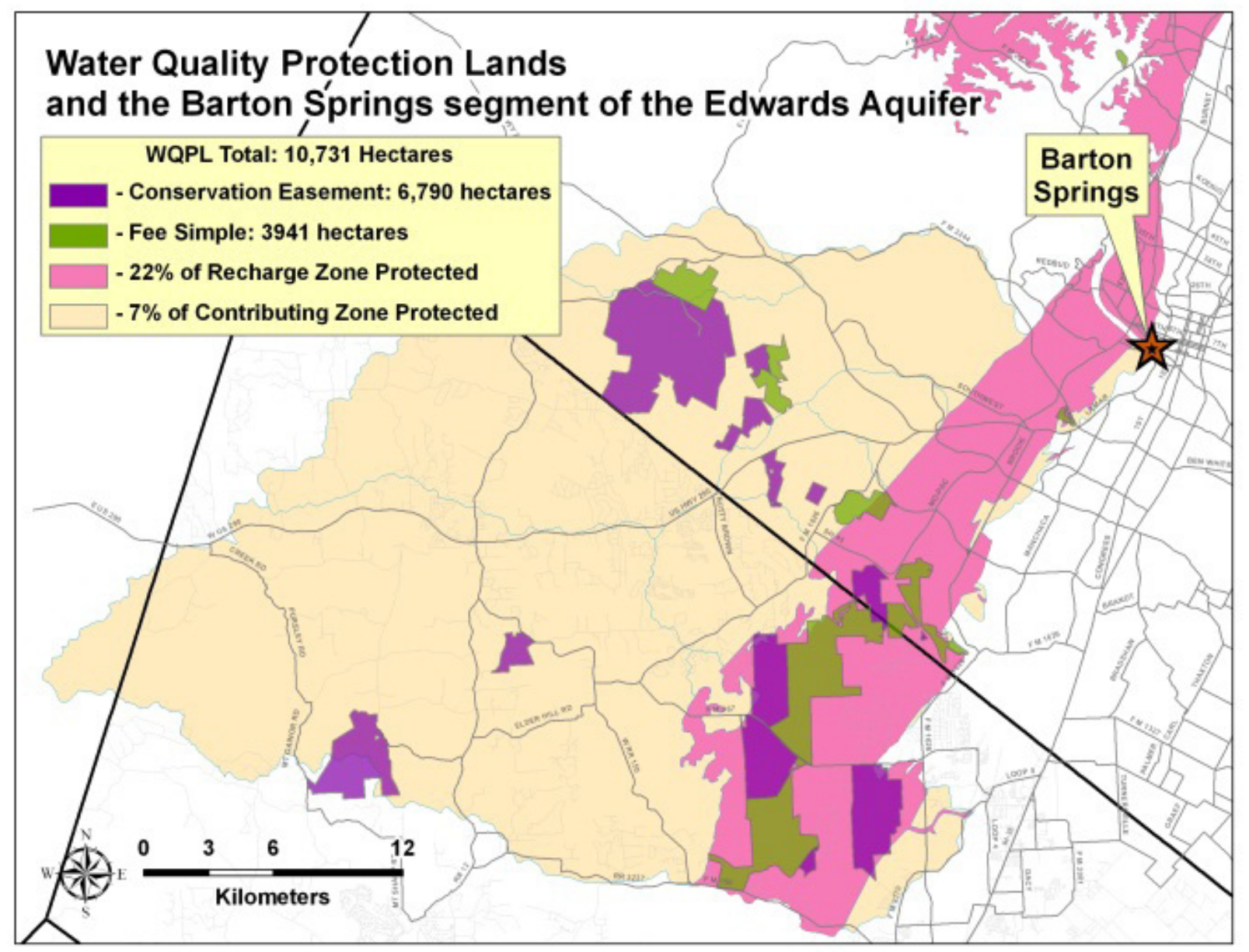

Figure 1. Map of land protected by the Water Quality Protection Lands program as of October 2012.

Further, various studies from Texas have shown additional water yield following brush management (Thurow and Hester 1997, Dugas and Wright 1998, Huang et al 2006, Saleh et al 2009, Banta and Slattery 2011). This has not been without controversy (Wilcox et al 2005, Wilcox et al 2008, Wilcox and Huang 2010), but ultimately the conditions that are most ideal for brush management from a water yield standpoint are well represented on the recharge zone lands protected by the WQPL Program: that is, a shallow soil overlaying a highly fractured subsurface where water can quickly be transported underground (Wilcox et al 2006).

The WQPL Program conducts ecological restoration activities on land held in fee simple to restore the ecosystems back to or maintain their native ecological states of grasslands and savannas (Land Management Planning Group 2001, Lady Bird Johnson Wildflower
Center 2010). These are the same ecosystems that the literature has demonstrated yield the greatest quantity of water. Work conducted in this regard utilizes a number of tools to manage brush and encourage grass restoration, including mechanical thinning, prescribed fire and native grass seeding. The work is conducted to be as low impact as possible to avoid erosion and other negative consequences on the land.

Balancing water quality and water quantity can be challenging and at times counterproductive, but again the literature has indicated improved water quality under grassland settings compared to other ecological states (Banta and Slattery 2011). In the case discussed herein, the restoration of native grasslands and savanna ecosystems in the recharge and contributing zones has the potential to further protect or even improve water quantity and water quality at Barton Springs. 


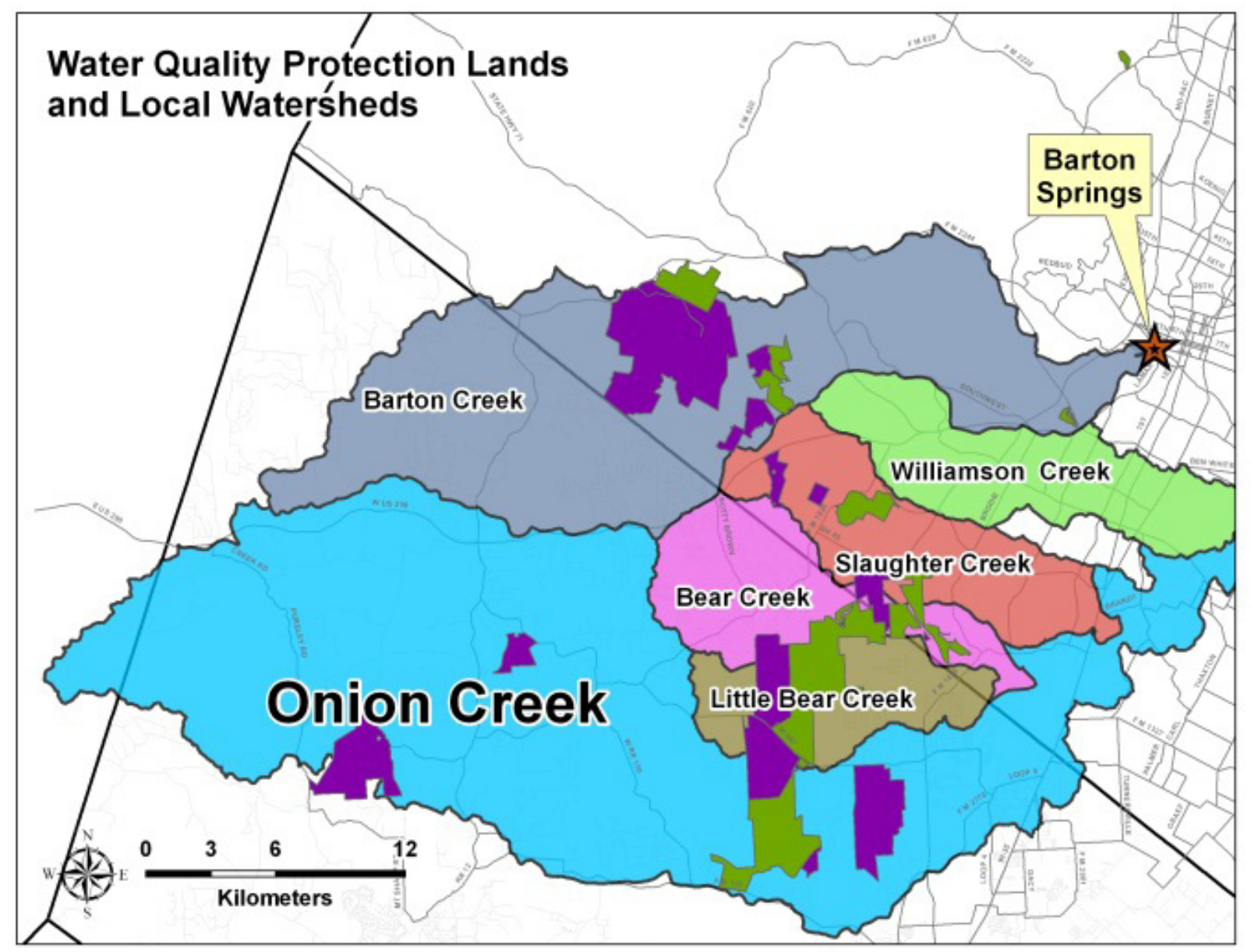

Figure 2. Map of watersheds in the area protected by the Water Quality Protection lands.

\section{Karst Management}

Once the land is protected and opportunities for optimizing the quantity and quality of water are implemented by land management, the last integral action is to protect the function of karst features. Locating and identifying karst features is an important first step, but this also has to be followed up with prioritizing features in terms of potential to transmit water. Logically, features located in streams beds, such as swallets, would rise above typical upland features in terms of absolute recharge (Hauwert et al 2005), but these upland features should not be discounted. For example the WQPL has at least two upland features with internal drainage basins approaching 24 hectares each. Such internal drainage basins can recharge up to 42 percent of the rain that falls within such a basin (Hauwert et al 2005). A swallet by comparison may have a drainage basin measured in square kilometers. That said, a swallet is unlikely to be able to transmit this total volume due to orifice size and capacity (Hauwert 2009)
Streams over the recharge zone in central Texas are frequently ephemeral in nature and under such conditions may not see appreciable flows for several years. Yet the management of karst features in streams frequently has the highest potential for recharging the largest volume of water over the longest time and accordingly receives the bulk of attention on the WQPL. As a case in point, one feature in Onion Creek (Figure 3) has been estimated to take in up to $425 \mathrm{l} / \mathrm{s}$ of water while the creek is flowing (Hauwert 2012).

Swallets can have their function impaired by their success in capturing water as this process also brings in substantial volumes of organic matter, sediment and rocks included in the bed load of the streams in which they are located. Over time this debris can plug swallets and negatively impact their function. Over a period of geologic time, such features are likely to close and open in some measure of equilibrium. However, in managing 


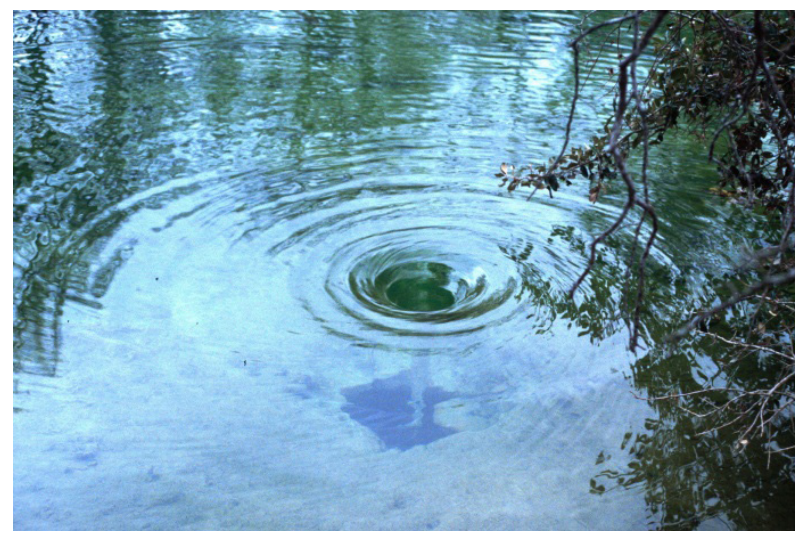

Figure 3. Photo of a swallet recharging on Onion Creek.

such areas to positively impact the quality and quantity of water reaching a spring on a human time scale, steps must be taken to keep the function of existing swallets in proper functioning condition rather than waiting for formation of new swallets. This is even more of an acute need when additional demands are made on an aquifer without any offsetting decreases in usage or increases in recharge.

The WQPL Program uses a variety of simple techniques to manage such features to maintain their function. Once a swallet is located, it is evaluated to help determine its importance. If it has the potential to provide significant recharge, a grate will be installed above it to help prevent debris from collecting within the swallet.

Further refinement of these grates has resulted in fine debris covers attached externally to these grates. Such debris covers are structurally weak, but are supported by the initial grate and removable without affecting the underlying grate (Figure 4). This has the benefit of blinding quickly with floating organic debris collecting on the fine grates under flood flows (Figure 5). The blinding of the grate then keeps the sediment associated with the initial flood pulses from passing through the grate. Naturally, this also prevents a large amount of water from reaching the feature, however, as this part of the flood flow is frequently of low quality, it is just as well avoided. The grates can then be cleaned manually once the peak of the flow has passed and allow the cleaner portion of the stream flow to be captured. This helps prevent the plugging of such features deep within the swallet such that maintenance of the grates on the surface is usually sufficient to keep the swallets in proper functioning conditions. Prior to the use of these grates it would be necessary to wait for a dry period to enter the caves and remove any debris plugs from deeper inside the feature.

These swallets likely owe their origin to dissolution by Onion Creek, as they have a strong vertical component (Hauwert 2013). White (1988) noted that caves carrying water through the vadose zone tend to stair step (i.e. have vertical drops), whereas caves formed at the water table tend to have a strong horizontal component. The humanly explored vertical depths of these features are relatively shallow, reaching at most only 9 to 10 meters as creek alluvial infill is excavated. Most of these swallets become constricted and horizontal in nature at the current limits of human exploration.

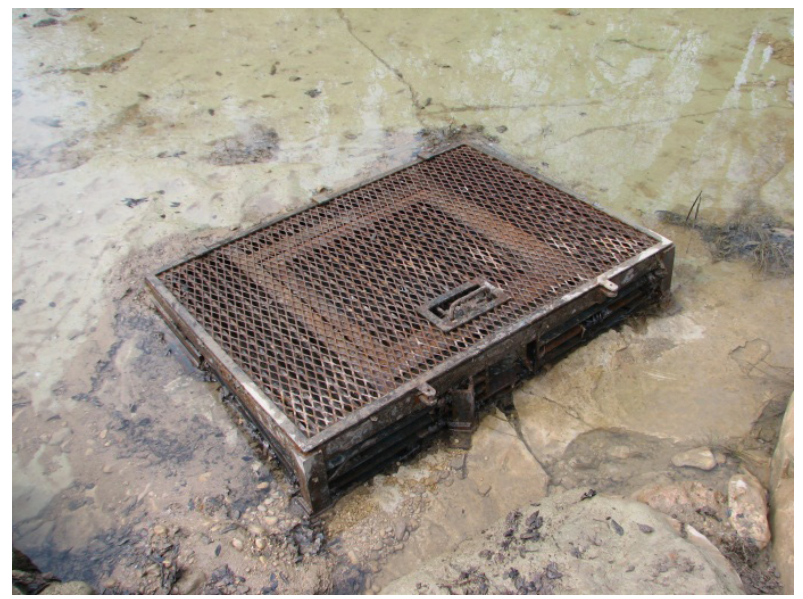

Figure 4. Example of swallet grate with fine debris cover.

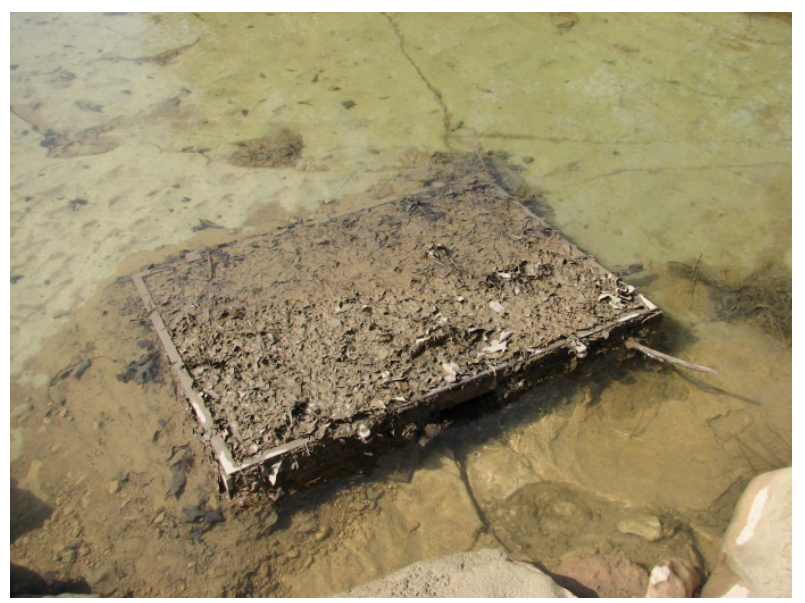

Figure 5. Example of swallet grate with fine debris cover after storm event and prior to manual cleaning. 
Once grated, some swallets can then be excavated to remove accumulated sediment with very little accumulation of new sediment. This can allow the unencumbered passage of water with less re-suspension or movement of old sediment. Few terrestrial organisms survive the periodic and occasionally long lasting inundations, but contractors doing such excavations are required to have U.S. Fish and Wildlife Service permits for working with endangered karst invertebrates.

In one example of this sort of excavation, a former landowner who was raised on the property, likely around the $1950 \mathrm{~s}$ or $1960 \mathrm{~s}$, reported a frequent whirlpool originating at a known swallet. No whirlpool had been reported or identified in recent time at this location and dye tracing showed it had a much longer travel time to Barton Springs than did a nearby feature also on Onion Creek (BSEACD 2003), albeit under a different flow regime. It seemed likely that 50 years of floodborn sediment might be preventing this feature from functioning properly. However, it is hoped that removing this sediment in combination with the addition of grates will return this swallet to proper functioning condition. The project is ongoing but over 38 meters $^{3}$ sediment and debris has been removed to date.

Upland features require much less attention, as they are frequently less prone to becoming plugged by debris, and proper functioning condition is maintained in these features by vegetation management that helps reduce erosion into the features. Frequently, upland features may also be home to karst invertebrates that could be endangered and may require the cave be protected as a refuge for such organisms versus being managed as a recharge feature.

\section{Conclusions}

The Water Quality Protection Lands were established to help protect a portion of the City's water supply, namely Barton Springs. The methods of this protection began with the purchase of land and the protection of additional land with conservation easements leading to the protection of over 10,730 hectares.

The WQPL Program went further and is implementing a land management plan to manage the land owned in fee simple to optimize the quality and quantity of water leaving the lands and recharging into the Barton Springs segment of the Edwards Aquifer. Techniques including those associated with ecological restoration are used to restore or maintain the vegetation as native grasslands and savannas, which have been shown to yield greater water than more woody landscapes. Finally, to ensure that water recharging off these lands can continue to benefit Barton Springs, karst features, and especially swallets, are managed and restored to proper functioning condition and protected from sedimentation that could impede or obstruct recharge.

\section{References}

Banta JR, Slattery RN. 2011. Effects of brush management on the hydrologic budget and water quality in and adjacent to honey Creek State Natural Area, Comal County, Texas, 2001-10. US Department of Interior, US Geological Service. Scientific Investigations Report 2011-5226.

Bray WL. 1904. The timber of the Edwards Plateau of Texas; its relation to climate, water supply and soil. USDA Bureau of Forestry Bulletin No. 49.

BSEACD. 2003. Summary of groundwater dye tracing studies (1996-2002) Barton Springs Segment of the Edwards Aquifer, Texas. Barton Springs / Edwards Aquifer Conservation District and the City of Austin. Unpublished summary report.

City of Austin. 1998. 1998 May Bound Elections. brochure.

Davie T, Fahey B. 2005. Forestry and water yield current knowledge and further work. New Zealand Journal of Forestry Feb:3-8

Dugas WA, Wright P. 1998 Effects of removal of Juniperus Ashei on evapotranspiration and runoff in the Seco Creek watershed. Water Resources Research 34(6) 1499-1506.

Dunn, L. 2007. The Unforeseen. New Yorker Films Video/Cinema Guild.

Fowler NL, Simmons MT. 2008. Savanna dynamics in Central Texas: Just succession? Applied Vegetation Science 12:23-31.

Hamilton LS. 2008. Forests and Water: A thematic study prepare in the framework of the Global Forest Resources Assessment 2005. Rome. Food and Agricultural Organization of the United Nations. FAO Forestry Paper 155.

Hauwert N, Johns D, Aley T, Sansom, J. 2004a, Groundwater tracing study of the Barton Springs Segment of the Edwards Aquifer, southern Travis and northern Hays counties, Texas. Report by the Barton Springs/Edwards Aquifer Conservation District and City of Austin Watershed Protection Department. 110p and appendices. 
Hauwert N, Johns D, Hunt B, Beery J, Smith B, and Sharp JM. 2004b. Flow systems of the Edwards Aquifer Barton Springs Segment interpreted from tracing and associated field studies. IN: Edwards Water Resources In Central Texas, Retrospective And Prospective Symposium Proceedings, San Antonio, Hosted by the South Texas Geological Society and Austin Geological Society. 18 p.

Hauwert N, Litvak ME, Sharp JM. 2005. Characterization and water balance of internal drainage sinkholes. In: Beck B. ed: Proceedings of the Ninth Multidisciplinary Conference Sinkholes and the Engineering Impacts of Karst. Geotechnical Special Publications No. 144:188-200.

Hauwert N. 2009. Groundwater Flow and Recharge within the Barton Springs Segment of the Edwards Aquifer, Southern Travis County and Northern Hays County, Texas [dissertation]. Austin (TX):

University of Texas at Austin, Texas. $328 \mathrm{p}$

Hauwert N. 2012. Recharge to the Barton Springs segment of the Edwards Aquifer: Major creek channel and river contributions. City of Austin short report (in progress).

Hauwert N. 2013. Personal Communication.

Huang Y, Wilcox BP, Stern L, Perotto-Baldivieso H. 2006. Springs on rangeland: Runoff dynamics and influence of woody plant cover. Hydrological Processes 20:3277-3288.

Hunt BB, Smith BA, Campbell S, Beery J, Hauwert N, Johns D. 2005. Dye tracing recharge features under high flow conditions, Onion Creek, Barton Springs segment of the Edwards Aquifer, hays County, Texas. Austin Geological Society Bulletin 1:70-86.

Hunt BB, Smith BA, Beery J, Johns D, Hauwert N. 2006. Summary of 2005 groundwater dye tracing, Barton Springs segment of the Edwards Aquifer, hays and Travis Counties, Central Texas. Barton Springs Edwards Aquifer Conservation District Report of Investigations 2006-0530.

Land Management Planning Group. 2001. Recommended land management for the Water Quality Protection Lands, Austin, Texas. 89 p.

Lady Bird Johnson Wildflower Center. 2010. Recommended land management for the Water Quality Protection Lands, Austin, Texas. 110 p.

LeMaitre DC, van Wilgen BW, Gelderblom CM, Bailey C, Chapman RA, Nel JA. 2002. Invasive alien trees and water resources in South Africa: Case studies of the costs and benefits of management. Forest Ecology and Management 160:143-159.

Mark AF, Dickinson KJM. 2008. Maximizing water yield with indigenous non-forest vegetation: a New Zealand perspective. Frontiers in Ecology and the Environment 6(1): 25-34.
Saleh A, Wu H, Brown CS, Teagarden FM, McWilliams SM, Hauck LM, Millican JS. 2009. Effects of brush control on evapotranspiration in the North Concho River watershed using the eddy covariance technique. Journal of Soil and Water Conservation 64(5):336-349.

Smeins FE, Fuhlendorf SD. 1997. Biology and ecology of Ashe (blueberry) juniper. IN: Taylor CA (ed) 1997 Juniper Symposium, 1997 Jan 10-11: San Angelo, TX. Technical Report 97-1. Texas Agricultural Experiment Station, Texas A\&M University System.

Smith A. 2012. The SOS Ordinance turns 20: Remembrances of an election that changed Austin's political Environment. The Austin Chronicle, August 3, 2012.

Thurow TL. 1998. Assessment of brush management as a strategy for enhancing water yield. Proceedings of the 25th Water for Texas Conference :Water Planning" Strategies for Senate Bill 1". Texas Water Resources Institute.

Thurow TL, Hester JW. 1997. How an increase or reduction in juniper cover alters rangeland hydrology. IN: Taylor CA (ed) 1997 Juniper Symposium, 1997 Jan 10-11: San Angelo, TX. Technical Report 97-1. Texas Agricultural Experiment Station, Texas A\&M University System.

White WB. 1988. Geomorphology and Hydrology of Karst Terrains. Oxford University Press, Oxford. 464 p.

Wilcox BP, Owens MK, Knight RW, Lyons RK. 2005 Do woody plants affect streamflow on semiarid karst rangelands? Ecological Applications 15(1):127-136.

Wilcox BP, Owens MK, Dugas WA, Ueckert DN, Hart CR. 2006. Shrubs, streamflow, and the paradox of scale. Hydrological processes 20:3245-3259.

Wilcox BP, Huang Y, Walker JW. 2008. Long term trends in streamflow from semiarid rangelands: Uncovering drivers of change. Global Change Biology 14:1676-1689.

Wilcox BP, Huang Y. 2010. Woody plant encroachment paradox: Rivers rebound as degraded grasslands convert to woodlands. Geophysical Research Letters 37:L07402.

Wu XB, Redeker EJ, Thurow T. 2001 Vegetation and water yield dynamics in an Edwards's Plateau watershed. Journal of Range Management 54:98-105. 
